написании рукописи. Окончательная версия рукописи была одобрена всеми авторами. Авторы не получали гонорар за исследование.

\section{ЛИТЕРАТУРА}

1. Клиническая ценность определения антигенсвязывающих клеток у больных брюшным тифом и другими заболеваниями: метод. рекомендации / Ф.Ю. Гариб, Н.И. Гурарий, Ю.И. Афанасьев [и др.]. - Ташкент, 1983. -40 c.

2. Диагностическое значение показателей антигенсвязывающих лимфоцитов в оценке поражения органов при инфекционной и неинфекционной патологии / Н.Г. Гулямов, Х.Ю. Ахмедова, Т.К. Далимов [и др.] // Инфекция, иммунитет и фармакология. - 2005. № 3. - С.115-118.

3. Гулямов, Н.Г. Иммунологическая диагностика органопатологии при бруцеллезе: метод. рекомендации / Н.Г. Гулямов, Х.Ю. Ахмедова, С.Д. Игамбердиева. Ташкент, 2012. - 20 c.

\section{REFERENCES}

1. Garib FJu, Gurarij NI, Afanas'ev Jul et al. Klinicheskaja cennost' opredelenija antigensvjazyvajushhih kletok u bol'nyh brjushnym tifom i drugimi zabolevanijami: metodicheskie rekomendacii [Clinical value of determination of antigen-binding cells in patients with typhoid fever and other diseases: guidelines]. Tashkent. 1983; 40 p.

2. Guljamov NG, Ahmedova HJu, Dalimov TK, Imamova IA, Juldasheva FZ. Diagnosticheskoe znachenie pokazatelej antigensvjazyvajushhih limfocitov $v$ ocenke porazhenija organov pri infekcionnoj i neinfekcionnoj patologii [Diagnostic value of lymphocyte antigen in the assessment of organ damage in infectious and noninfectious diseases]. Infekcija, immunitet i farmakologija [Infection, immunity and pharmacology]. 2005; 3: 115-118.

3. Guljamov NG, Ahmedova HJu, Igamberdieva SD. Immunologicheskaja diagnostika organopatologii pri brucelleze: metodicheskie rekomendacii [Immunological diagnosis of brucellosis in the organopathology: guidelines]. Tashkent. 2012; 20 p.

(C) T.P. Lagutkina, M.M. Bahlol, 2016

удК 615.1:339.138(100)

DOI: $10.20969 / v s k m .2016 .9(1) .40-45$

\title{
STANDARDIZATION AND ADAPTATION REVIEW IN PHARMACEUTICAL MARKETING PROMOTIONS
}

\author{
LAGUTKINA TATIANA P., D. Pharm. Sci., professor of the Department of management and economics of pharmacy, \\ medical faculty, Russian People's Friendship University, Russia, 117513, Moscow, Leninski av., 135-1-591, \\ e-mail: Lagutkina.t@gmail.com, citizenship: Russia \\ BAHLOL MOHAMMED MOSTAFA HOSSNI ABDELAZIZ, graduate student of the Departament of management \\ and economics of pharmacy, medical faculty, Russian People's Friendship University, Russia, 117198, Moscow, \\ Mikluho-Maklaj str., 21, build. 1, e-mail:Ph_hossni@yahoo.com, citizenship: Egypt
}

\begin{abstract}
Aim. International business has dramatically been expanding. Pharmaceutical companies expanded in foreign markets in order to survive. Importance of international marketing strategy has been rising due to increase of foreign market percentage from total world market and foreign competition. Accordingly, pharmaceutical companies marketing strategy should be coordinated in different countries. Material and methods. Reviewing of an immense argumentation with regard to appropriate marketing strategy in different markets of different countries. Results and discussion. There are two marketing strategy choices, i.e., either standardization or adaptation. There are both advantages and disadvantages of standardization and adaptation in pharmaceutical marketing promotion. Conclusion. There are a lot of factors affecting standardization and adaptation. These factors are related to the product, the hosting market and the pharmaceutical company itself. Mixing both standardization and adaptation in marketing strategy of pharmaceutical companies should be done in a real life practice. Pharmaceutical companies should aggregate the worldwide heterogeneous market into homogenous clusters. These aggregations depend on similarities of attitude to demand or offers between countries in each cluster and can be done at cross cultural or geographical level.
\end{abstract} Key words: standardization, adaptation, factor, marketing strategy, pharmaceutical company.

For reference: Lagutkina TP, Bahlol MM. Standardization and adaptation review in pharmaceutical marketing promotions. The Bulletin of Contemporary Clinical Medicine. 2016; 9 (1): 40—45.

\section{СТАНДАРТИЗАЦИЯ И АДАПТАЦИЯ В ФАРМАЦЕВТИЧЕСКОМ МАРКЕТИНГЕ}

ЛАГУТКИНА ТАТЬЯНА ПЕТРОВНА, докт. фарм. наук, профессор кафедры управления и экономики фармации, медицинский факультет, Российский университет дружбы народов, Россия, 117513, Москва, Ленинский проспект, 135-1-591, e-mail: lagutkina.t@gmail.com, гражданство: Россия

БАХЛОЛ МОХАММЕД МОСТАФА ХОССНИ АБДЕЛАЗИЗ, аСпирант кафедры управления и экОномики фармации, медицинский факультет, Российский университет дружбы народов, Россия, 117198, Москва, ул. Миклухо-Маклая, 21, корпус 1, e-mail: Ph_hossni@yahoo.com, гражданство: Египет

Реферат. Цель. Международный бизнес расширяется. Чтобы продолжать существовать, фрармацевтические компании увеличивают сферу влияния на зарубежных рынках. Важность международной маркетинговой стратегии растет за счет увеличения процента зарубежного рынка от общего числа мирового рынка и международной конкуренции. Следовательно, маркетинговые стратегии фрармацевтических компаний должны быть согласованы в различных странах. Материал и методы. Проанализировано огромное число обоснований в отношении соответствующей стратегии маркетинга на различных рынках разных стран. Результаты и их обсуждение. Существует два варианта маркетинговой стратегии: стандартизация или адаптация. В развитии фармацевти- 
ческого маркетинга есть свои преимущества и недостатки как стандартизации, так и адаптации. Заключение. Есть много фракторов, влияющих на стандартизацию и адаптацию. Эти фракторы связаны с продуктом, рынком размещения и самой фармацевтической компанией. В практике реальной жизни должно произойти смешивание стандартизации и адаптации в маркетинговой стратегии фармацевтических компаний. Фармацевтические компании должны объединить всемирный неоднородный рынок в однородные кластеры. Эти объединения основаны на сходстве отношения к востребованности или предложениям между странами в каждом кластере и могут быть созданы на межкультурном или географическом уровнях.

Ключевые слова: стандартизация, адаптация, фактор, маркетинговая стратегия, фармацевтическая компания.

Для ссылки: Лагуткина, Т.П. Стандартизация и адаптация в фармацевтическом маркетинге / Т.П. Лагуткина, М.М. Бахлол // Вестник современной клинической медицины. — 2016. — Т. 9, вып.1. — С.40—45.

1. Introduction. Internationalization of business in general has dramatically been increasing. Technological expansion, liberalization and global competition led to this rapid growth. Companies expanded their activities in foreign markets in order to survive. Importance of international marketing strategy has been increasing due to increase of foreign competition and foreign market percentage from total world market. Accordingly, pharmaceutical marketing activities should be coordinated in different markets. Market promotion tools are the most noticeable and culturebound function. They are applied to communicate with different audience of companies and influence them. Results of marketing promotion of two pharmaceutical companies might differ, although the same resources were allocated. The right marketing strategy in different markets of different countries is a big debate. There are two choices, i.e., either standardization or adaptation. For standardization, the pharmaceutical company uses one strategy only in different countries. Therefore the pharmaceutical company assumes that all customers have the same or similar needs. For adaptation, the pharmaceutical company does not consider similarity of customers in different countries, but establishes a specific marketing strategy for each country. These choices are due to different factors such as economic, cultural and legal issues in each market.

2. Historical Argumentation between Standardization and Adaptation. There is an argumentation between standardization and adaptation of activities of companies working in more than one country in international marketing. Levitt (1983) argued that «a powerful force drives the world toward a converging commonality, and that force is technology» [1]. Boddewyn et al. (1986) argued that there are national differences in habits, regulations, tastes and technical requirements which prevent standardization [2]. According to Levitt; there is a homogenous international market in the world, the driving force is advanced technology and standardization is the right way in international marketing. On the other hand, according to Boddewyn, this homogeneity is absent. In fact, academics have an orientation towards adaptation, because of their viewpoint, i.e., absence of international homogenous market and similarities of consumers and standardization are impossible. In contrast, practitioners are fluctuating between standardization and adaptation [3, 4] (figure).

3. Globalization and Standardization. The term «globalization» came from the term «global» which means world scale in the late XIX century. It became popular in the early $X X$ century with high rate of publications. From 2002 to 2008 , publications correlated to this topic were more than 1100 publication per year $[5,6]$.

Global companies are seeking to standardize their products and try to keep standardization of their issues with high degree, because of international market homogeneity. Standardization means «creating uniform business processes across various divisions or locations». This is done with considering that the company knows what is good for the customer [5, 7-11].

Global competitors are seeking standardization in order to decrease international cost. For these companies, the global market is homogeneous. The company believes that its patronage will be exponentially expanded and it will consequently attract more customers as they will more prefer lower cost than local preference. Global companies know the urgent need for worldwide competition and vigorously work toward global convergence. Their products are being offered for standardized international needs in worldwide market with lower price [1].

According to standardization, pharmaceutical companies assume that all customers all over the world have the same needs. A lot of economics supported globalization and standardization, because of their positive aspects. Advantages of standardization (table) are valuable and we can enumerate them. Standardization is focused on economies of scale which will lead to decreasing total costs. In advertising

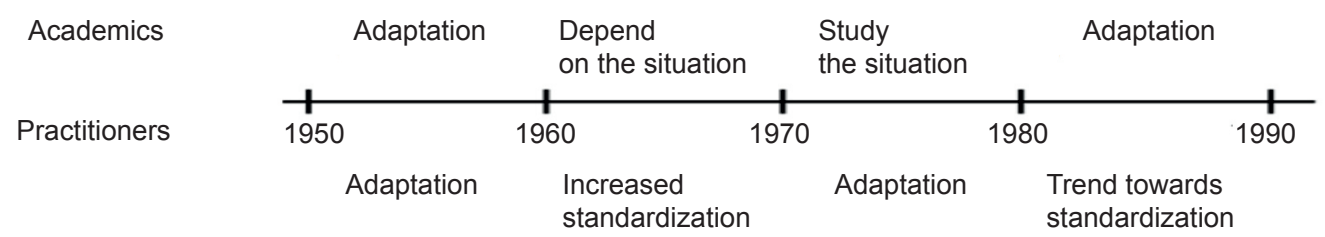

Different Approaches to International Advertising Strategies over time for Academics and Practitioners (Source: Madhu Agrawal, 1995) 
Advantages and Disadvantages of Standardization and Adaptation

\begin{tabular}{|c|c|c|}
\hline Marketing Strategy & Advantages & Disadvantages \\
\hline Standardization & $\begin{array}{l}\text { - Economies of scale. } \\
\text { - Decrease of total costs. } \\
\text { - International customers will be less } \\
\text { confused. } \\
\text { - Strong brand and company image. } \\
\text { - Synergism of marketing activity. } \\
\text { - Quality enhancement }\end{array}$ & $\begin{array}{l}\text { - Mismatching actual customer needs. } \\
\text { - Less sensitivity to changes in the host market. } \\
\text { - Less competitiveness \& competitive advantages. } \\
\text { - The company will be seen as a foreign company. } \\
\text { - Lower customers trust. } \\
\text { - Decrease of total sales. } \\
\text { - Less profits }\end{array}$ \\
\hline Adaptation & $\begin{array}{l}\text { - Matching actual customers' needs. } \\
\text { - Customers trust. } \\
\text { - High sensitivity to changes in the host } \\
\text { market. } \\
\text { - High competitiveness. } \\
\text { - Competitive advantages. } \\
\text { - Increase of total sales. } \\
\text { - High profits }\end{array}$ & $\begin{array}{l}\text { - Increase of total costs. } \\
\text { - Variable qualities. } \\
\text { - Confusion of international customers. } \\
\text { - Difficult in synergism of marketing activity }\end{array}$ \\
\hline
\end{tabular}

preparation, the cost is decreased; international customers will be less confused as advertising is identical worldwide. Other advantages of standardization are represented in strong brand image and company image due to synergism of marketing activity. Moreover, quality will be enhanced by standardization, not only lowering of total cost. The international company is gaining experience and knowledge from a lot of companies, also quality of standards and preferences come from a global viewpoint. Therefore, the company will be able to increase quality and improve resources management through standardization and globalization strategy [12-14].

4. Adaptation. Most researchers apply the term adaptation as the extreme opposite of standardization $[15,16]$. According to Mediana and Duffy, 1998; adaptation is "obligatory modification of standards (tangible and/or intangible attributes) of products intended for the country's inner target market with the aim of making the product suitable for conditions of foreign market environment» [17]. Adaptation is setting different strategies of the marketing mix [18]. For international advertising strategy, adaptation for each market should be done, as a separate entity. That action is taken because each market has its own politics, legalizations, culture, economic situation and different medical needs. Academicians are considered with contingency approach. The decision is not to completely standardization or adaptation concerning the applied strategy, but depends on the actual situation in a particular market [19-24]. This situation depends on different environmental factors.

From this viewpoint, pharmaceutical worldwide market is not a homogeneous market. Even in one country there are different market segments with different demand and needs. For example, market segmentation in one country or nation will lead to alteration of product features to meet target demand and needs [25]. These changes start from packaging and extend to product main features. If this difference exists in a country, so it is stronger in different countries and in the worldwide market [26]. Large pharmaceutical companies which operate in only one nation may be unable to standardize their products. They may have product lines instead of a single product version. These product lines exist because of different ethnics and institutional differences. The companies may be forced to customize one product to meet the needs of different segments, because they believe that success requires searching for similar opportunities in similar segments. Many companies tried to standardize their products and exported it directly without adaptation. Therefore, they have miserably failed [1].

Advantages of adaptation (look through table) depend on buyer behavior difference in each market and are influenced by his preferences. In case when product related attributes are the same; evaluation of these attributes by the buyer will be different from country to another. For pharmaceutical companies to successfully compete in the host market, they must adapt their strategy for this market. The company's advertising strategy should be adapted to the host market. The pharmaceutical company may not prefer to be seen as a foreign company, as the customer prefers being familiar with a local company. The company must also adapt its strategy, products, marketing activities and advertising to the host company's legal rules and culture. Accordingly, the company will gain customer trust and get high profits. These profits result from adoption to actual customer needs and total sales increase. In addition, the company will gain high sensitivity to changes in the host market. All these interactions will lead to high competitiveness, competitive advantage and profits [16, 27, 28].

5. Factors that Affect Standardization and Adaptation. There are a lot of factors that affect degree of standardization and adaptation of marketing promotion of pharmaceutical companies, because they have an effect on communication process between companies and their customers.

Toyne and Walters (1989) refer to the following factors such as: cultural, language, social, legal, competitive and economic differences [29].

De Mooij (1994) agreed with Toyne and Walter that legal, cultural, social, economic issues and competition have a great effect on standardization and adaptation. In addition, he argued that choice of complete standardization or adaptation of marketing strategy is rare, where the right choice is the applied degree of standardization or adaptation. This degree is related to a lot of factors, such as: product category, product life cycle, branding, positioning of brand, media, market affluence [30]. 
Mulbacher (1999) argued that standardization degree is affected by a lot of factors. He divided them into four main groups: internal environment (international experiences, corporate management attitude, international orientation goals, cost of R\&D); product (product nature and uniqueness, cultural specificity), market (stage of life cycle, urbanization degree, structure of distribution system, technology degree, price sensitivity) and macro environment (regulations, politics, technical and social issues, geography) [31].

Papavassiliou and Stathakopoulos (1997) defined a lot of factors that affect degree of standardization and adaptation in advertising and conceived a framework for that purpose. They categorized these factors into three main groups: local variables (culture, economy, legal, competitions), firm variables (managerial and financial issues, nature of products), intrinsic variables (advertising objectives and creativity, expenditure, government control, other tools of communication mix, barriers and supportive activities) [13].

Researchers are different in their definitions, recognition and categorization of different factors that can affect marketing strategy. All of them mentioned factors that affect marketing promotion strategy of pharmaceuticals in different degrees. Although there are apparent differences in classification of mentioned factors by researchers, difference between researches is due to orientation of their categorization of these factors. We can summarize them to: product related factors, hosting market related factors and company related factors.

We can stress that standardization orientation has important benefits, for example, economies of scale, synergies of non-complicated marketing activities across markets, because international market seems to be homogenous from standardization viewpoint. On the other hand, adaptation orientation has important benefits, for example, competitive advantages and higher sales, because of different consumers' needs in different cultures and countries. But each of them has its drawbacks, for example, standardization leads to decrease of total sales and adaptation leads to increase of total cost. There are limits for the factors which have influence on international marketing strategy of companies.

One total marketing strategy, i.e., complete standardization or complete adaptation cannot be literally applied in practical life. Accordingly, there is a need for a solution to pharmaceutical companies. From our viewpoint, the recommended solution for the dilemma is a mixture that consists of both standardization and adaptation marketing strategy. The international pharmaceutical company should aggregate similar countries in a separate section. Therefore, it will have clusters formed of similar countries. This will help the companies to have more standardized marketing strategy to each homogenous cluster and simultaneously more adapted marketing strategy for this cluster. Similarities of attitude to demand or offers between countries can be done at different levels: crosscultures level or geographical level.

6. Conclusion. As a result of profound understanding of standardization and adaptation of marketing promotion in pharmaceutical market, we can conclude that there are both advantages and disadvantages of standardization and adaptation in pharmaceutical marketing promotion. The main motive of standardization is cost saving. By directing marketing promotion at central level, the company can utilize its full creative competence and uniform image. On the other hand, adaptation of pharmaceutical marketing promotion is necessary due to difference in factors that have influence on marketing strategy. There are a lot of factors which affect standardization and adaptation. These factors are related to the product itself, the hosting market and the pharmaceutical company itself. The recommended solution to avoid drawbacks of both complete standardization and complete adaptation is to reach a balanced pharmaceutical marketing strategy, because complete standardization or complete adaption are not recommended to be applied in real life practice. A mixture of both standardization and adaptation of marketing strategy of pharmaceutical companies should be utilized. Pharmaceutical companies can aggregate the worldwide heterogeneous market into homogenous clusters. These companies will increase level of standardization to each similar cluster and simultaneously the applied strategy to each cluster will be adapted to this specific cluster. Clusters aggregation depends on similarities of attitude to demand or offers between countries in each cluster and can be done in cross cultural or geographical level.

7. Further Research Implications. Although argumentation of standardization and adaptation is running for decades, there are a lot of issues to be investigated. Firstly, we recommend that of pharmaceutical companies' managers pay more attentions to new correlated factors and environment of different countries that are important to pharmaceutical marketing promotions. Secondly, it is significant to study physicians', pharmacists' and patients' reactions to standardizations and adaptation of marketing promotions. Thirdly, it is noteworthy to study results of standardization and adaptation of marketing promotion. Fourthly, it is important to investigate which tools of marketing promotion can be easily applied transboundary. Finally, it is considerable to study if there is an effect of country origin of pharmaceutical companies on standardization or adaptation of marketing promotion.

The transparency of study. The study did not have sponsorship. Authors are fully responsible for the provision of the final version of the manuscript for publication.

\section{ЛИТЕРАТУРА}

1. Levitt, $T$. The globalization of markets / T. Levitt // Harvard Business Review. - 1983. - Vol. 61(3). - P.69-81.

2. Boddewyn, J.J. Standardization in international marketing: isTed Levitt in fact right? / J.J. Boddewyn, R. Soehl, J. Picard // Business Horizon. - 1986. — Vol. 29(6). P.69-75.

3. Melewar, T. International advertising strategy: A review, reassessment and recommendation / T. Melewar, C. Vemmervik // Management Decision. - 2004. Vol. 42(7). - P.863-881.

4. Agrawal, M. Review of a 40-year debate in international advertising: Practitioner and academician perspectives 
to the standardization/adaptation issue / M. Agrawal // International Marketing Review. — 1995. — Vol. 12(1). P.26-48.

5. Scholte, J.A. What is globalization? The definitional issueagain / J.A. Scholte. - CSGR Working Paper, 2002. Vol. 109/02. - 48 p.

6. Globalization. In Merriam-Webster Online Dictionary 2010. - URL: http://www.merriam-webster.com/ dictionary/globalization (дата обращения: 26.01.2016).

7. Kotler, P. Global standardization-courting danger/P. Kotler // Journal of Consumer Marketing. - 1986. - Vol. 3(2). P.13-15.

8. Frankel, J.A. Measuring international capital mobility: a review / J.A. Frankel // The American Economic Review. 1992. - P.197-202.

9. Feenstra, R.C. Integration of trade and disintegration of production in the global economy / R.C. Feenstra // The journal of economic perspectives. -1998 . - Vol. 12, is. 4. - P.31-50.

10. Richen, A. Standardization or harmonization? you need both / A. Richen, A. Steinhorst // European Health Informatics, 2005. — Vol. 5. - URL: www. bPTrends.com (дата обращения: 26.01.2016).

11. Obstfeld, M. Global capital markets: integration, crisis, and growth / M. Obstfeld, A.M. Taylor. — New York: Cambridge University Press, 2004. - 354 p.

12. Theodosiou, $M$. Standardization versus adaptation of international marketing strategy: an integrative assessment of the empirical research / M. Theodosiou, L.C. Leonidou // International Business Review. - 2003. - Vol. 12, № 2 - P.141-171.

13. Papavassiliou, N. Standardization versus adaptation of international advertising strategies: towards a framework / N. Papavassiliou, V. Stathakopoulos // European Journal of Marketing. — 1997. — Vol. 31, № 7. — P.504-527.

14. Samiee, $S$. The influence of global marketing standardization on performance / S. Samiee, K. Roth // The Journal of Marketing. - 1992. - Vol. 56, is. 2. - P.1-17.

15. Douglas, S.P. The myth of globalization / S.P. Douglas, Y. Wind // Columbia Journal of World Business. — 1987. Vol. 22, is. 4. - P.19-29.

16. Szymanski, D.M. Standardization versus adaptation of international marketing strategy: an empirical investigation / D.M. Szymanski, S.G. Bharadwaj, P.R. Varadarajan // The Journal of Marketing. -1993 . - Vol. 57 , is. 4. P.1-17.

17. Medina, J.F. Standardization vs globalization: a new perspective of brand strategies / J.F. Medina, M.F. Duffy // Journal of Product \& Brand Management. - 1998. Vol. 7(3). - P.223-243.

18. Kuvykaité, R. Standardization/adaptation of marketing solutions in companies operating in foreign markets: An integrated approach / R. Kuvykaitè, M. Alimiené // Engineering economics. - 2008. - Vol. 1(56). P.37-47.

19. Pratt, E.E. Modern international commerce: Allyn and Bacon / E.E. Pratt // Journal of Marketing. - 1957. Vol. 21(4). - P.492-494.

20. Wang, $X$. Standardization or adaptation in international advertising strategies: The roles of brand personality and country-of-origin image / X. Wang, Z. Yang // Asian Journal of Business Research. - 2011. — Vol. 1(2). P. 25-36.

21. Marshall, S.W. International Advertising Strategy / S.W. Marshall, M.S. Roberts // The Handbook of International Advertising Research. - 2014. — Vol. 21. P.251-269.

22. Buzzell, R.D. Can you standardize multinational marketing? / R.D. Buzzell // Reprint Service, Harvard business review. — 1968. — № 49. - P.102-113.
23. Ryans, J.K. Is it too soon to put a tiger in every tank / J.K. Ryans // Columbia Journal of World Business. 1969. - Vol. 4(2). - P.69-75.

24. Miracle, G.E. International advertising principles and strategies / G.E. Miracle // MSU Business Topics. 1968. - Vol. 16(3). - P.29-36.

25. Smith, W.R. Product differentiation and market segmentation as alternative marketing strategies / W.R. Smith // The Journal of Marketing. - 1956. - Vol. 21(1). - P.3-8.

26. Dickson, P.R. Market segmentation, product differentiation, and marketing strategy/ P.R. Dickson, J.L. Ginter // The Journal of Marketing. - 1987. — № 51. - P.1-10.

27. Solberg, C.A. Standardization or adaptation of the international marketing mix: the role of the local subsidiary/ representative / C.A. Solberg // Journal of International Marketing. - 2000. — Vol. 8(1). - P.78-98.

28. Zou, S. The GMS: a broad conceptualization of global marketing strategy and its effect on firm performance / S. Zou, S.T. Cavusgil // Journal of Marketing. - 2002. Vol. 66(4). - P.40-56.

29. Toyne, B. Global Marketing Management: A Strategic Perspective / B. Toyne, P.G.P. Walters. - 1st ed. Boston: Allyn and Bacon, 1988. - 747 p.

30. Mooij, M.K. Advertising worldwide, Concepts, theories and practice of international, multinational and global advertising / M.K. Mooij, W.J. Keegan. - Hertfordshire: Prentice Hall, 1991. - 440 p.

31. Mülbacher, $H$. International Marketing: A Global Perspective / H. Mülbacher, L. Dahringer, H. Leihs. - Cengage Learning Business Press, 1999. - 768 p.

\section{REFERENCES}

1. Levitt T. The globalization of markets. Harvard Business Review. 1983; 61(3): 69-81.

2. Boddewyn JJ, Soehl R, Picard J. Standardization in international marketing: isTed Levitt in fact right? Business Horizon. 1986; 29 (6): 69-75.

3. Melewar T, Vemmervik C. International advertising strategy: A review, reassessment and recommendation. Management Decision. 2004; 42 (7): 863-881.

4. Agrawal M. Review of a 40-year debate in international advertising: Practitioner and academician perspectives to the standardization/adaptation issue. International Marketing Review. 1995; 12 (1): 26-48.

5. Scholte JA. What is globalization? The definitional issueagain. CSGR Working Paper. 2002; 109 / 02: 48 p.

6. Globalization. In Merriam-Webster Online Dictionary. 2010; Available from: http://www.merriam-webster.com/ dictionary/globalization.

7. Kotler P. Global standardization-courting danger. Journal of Consumer Marketing. 1986; 3 (2): 13-15.

8. Frankel JA. Measuring international capital mobility: a review. The American Economic Review. 1992: 197-202.

9. Feenstra RC. Integration of trade and disintegration of production in the global economy. The journal of economic perspectives. 1998; 12 (4): 31-50.

10. Richen A, Steinhorst A. Standardization or harmonization? you need both. European Health Informatics. 2005; 5: Available from: www. bPTrends.com.

11. Obstfeld M, Taylor AM. Global capital markets: integration, crisis, and growth. New York: Cambridge University Press. 2004; $354 \mathrm{p}$.

12. Theodosiou M, Leonidou LC. Standardization versus adaptation of international marketing strategy: an integrative assessment of the empirical research. International Business Review. 2003; 12 (2): 141-171.

13. Papavassiliou N, Stathakopoulos V. Standardization versus adaptation of international advertising strategies: towards a framework. European Journal of Marketing. 1997; 31 (7): 504-527. 
14. Samiee S, Roth K. The influence of global marketing standardization on performance. The Journal of Marketing. 1992; 56 (2): 1-17.

15. Douglas SP, Wind Y. The myth of globalization. Columbia Journal of World Business. 1987; 22 (4): 19-29.

16. Szymanski DM, Bharadwaj SG, Varadarajan PR. Standardization versus adaptation of international marketing strategy: an empirical investigation. The Journal of Marketing. 1993; 57 (4): 1-17.

17. Medina JF, Duffy MF. Standardization vs globalization: a new perspective of brand strategies. Journal of Product \& Brand Management. 1998; 7 (3): 223-243.

18. Kuvykaitè R, Alimienè M. Standardization/adaptation of marketing solutions in companies operating in foreign markets: An integrated approach. Engineering economics. 2008; 1 (56): 37-47.

19. Pratt EE. Modern international commerce: Allyn and Bacon. Journal of Marketing. 1957; 21 (4): 492-494.

20. Wang X, Yang Z. Standardization or adaptation in international advertising strategies: The roles of brand personality and country-of-origin image. Asian Journal of Business Research. 2011; 1 (2): 25-36.

21. Marshall SW, Roberts MS. International Advertising Strategy. The Handbook of International Advertising Research. 2014; 21: 251-269.

22. Buzzell RD. Can you standardize multinational marketing? Reprint Service. Harvard business review; 1968; 49: 102-113.
23. Ryans JK. Is it too soon to put a tiger in every tank. Columbia Journal of World Business. 1969; 4 (2): 69-75.

24. Miracle GE. International advertising principles and strategies. MSU Business Topics. 1968; 16 (3): 29-36.

25 . Smith WR. Product differentiation and market segmentation as alternative marketing strategies. The Journal of Marketing. 1956; 21 (1): 3-8.

26. Dickson PR, Ginter JL. Market segmentation, product differentiation, and marketing strategy. The Journal of Marketing. 1987; 51: 1-10.

27. Solberg CA. Standardization or adaptation of the international marketing mix: the role of the local subsidiary/ representative. Journal of International Marketing. 2000; 8 (1): 78-98.

28. Zou S, Cavusgil ST. The GMS: a broad conceptualization of global marketing strategy and its effect on firm performance. Journal of Marketing. 2002; 66 (4): 40-56.

29. Toyne B, Walters PGP. Global Marketing Management: A Strategic Perspective, 1st Ed. Boston: Allyn and Bacon. 1988; $747 \mathrm{p}$.

30. Mooij MK, Keegan WJ. Advertising worldwide, Concepts, theories and practice of international, multinational and global advertising. Hertfordshire: Prentice Hall. 1991; $440 \mathrm{p}$.

31. Mülbacher H, Dahringer L, Leihs H. International Marketing: A Global Perspective. Cengage Learning Business Press. 1999; $768 \mathrm{p}$.

\section{ИССЛЕДОВАНИЕ ЭФФЕКТИВНОСТИ, БЕЗОПАСНОСТИ И ПЕРЕНОСИМОСТИ СОЧЕТАННОГО ПРИМЕНЕНИЯ ПРЕПАРАТОВ ГЛЮКОЗАМИНА СУЛЬФАТА ( (АРТРАКАМ») И ХОНДРОИТИНА СУЛЬФАТА («АРТРАДОЛ») У ПАЦИЕНТОВ С ОСТЕОАРТРОЗОМ КОЛЕННЫХ СУСТАВОВ}

ЛАПШИНА СВЕТЛАНА АНАТОЛЬЕВНА, канд. меД. наук, доцент кафедры госпитальной терапии ГБОУ ВПО «Казанский государственный медицинский университет» Минздрава России, научный сотрудник научного отдела ГАУЗ «Республиканская клиническая больница МЗ РТ», Россия, 420012, Казань, ул. Бутлерова, 49, e-mail: svetlanalapshina@mail.ru

АФАНАСЬЕВА МАРИАННА АНАТОЛЬЕВНА, врач ревМатолоГичесКоГО отДеления ГАУЗ «РеспУбликанская клиническая больница МЗ РТ», Россия, 420064, Казань, Оренбургский тракт, 138

СУХОРУКОВА ЕЛЕНА ВАСИЛЬЕВНА, врач ревматологичеСКого отДеления ГАУЗ «Республиканская клиническая больница МЗ РТ», Россия, 420064, Казань, Оренбургский тракт, 138

АХТЯМОВ ИЛЬДАР ФУАТОВИЧ, докт. мед. наук, профессор, зав. кафедрой травматологии, ортопедии и хирургии экстремальных состояний ГБОУ ВПО «Казанский государственный медицинский университет» Минздрава России, главный научный сотрудник научного отдела ГАУЗ «Республиканская клиническая больница МЗ РТ», Россия, 420012, Казань, ул. Бутлерова, 49, e-mail: yalta60@mail.ru

МЯСОУТОВА ЛЕЙСАН ИЛЬДАРОВНА, асСИстент кафедры Госпитальной терапии ГБОУ ВПО «Казанский государственный медицинский университет» Минздрава России, Россия, 420012, Казань, ул. Бутлерова, 49

Реферат. Цель исследования - оценка эффективности и безопасности сочетанного применения препаратов «Артрадол» (хондроитина сульфрат) и «Артракам» (глюкозамина сульфат) у пациентов с остеоартрозом (ОА) коленных суставов. Материал и методы. Проведено комплексное обследование 30 пациентов с достоверным диагнозом ОА коленных суставов и выраженным болевым синдромом, средний возраст - $(58,7 \pm 5,1)$ года, длительность заболевания - $(5,9 \pm 2,9)$ года. В дополнение к получаемой терапии НПВП всем пациентам назначались препараты хондроитина сульфата («Артрадол») внутримышечно и глюкозамина сульфата («Артракам») чередованием через день на 2 мес. Эфрфективность терапии определялась через 1 и 2 мес лечения согласно динамике показателей суставного синдрома: интенсивность боли в суставе (ВАШ), окружность сустава, индекс WOMAC, потребность в НПВП, эффективность терапии по мнению пациента и врача. Результаты и их обсуждение. Через 2 мес комбинированной терапии препаратами глюкозамина и хондроитина сульфата наблюдалось достоверное $(p<0,05)$ уменьшение боли при движении, болезненности суставов при пальпации, окружности коленного сустава, снижение индекса WOMAC, времени прохождения расстояния в 15 м, потребности в НПВП, купирование локального воспаления в суставах. Эффективность терапии была оценена паци- 